\title{
Shrub Effects on Carbon Dioxide and Water Vapor Fluxes Over Grasslands
}

\author{
A. B. Frank ${ }^{1}$ and J. F. Karn ${ }^{2}$ \\ Authors are ${ }^{1}$ Plant Physiologist and ${ }^{2}$ Animal Scientist, USDA-ARS, Box 459, Hwy 6 S, Mandan, ND 58554.
}

\begin{abstract}
Temperate grasslands are a species-rich ecosystem that may be important in mitigating the increase in atmospheric $\mathrm{CO}_{2}$. The effect of shrub invasion on $\mathrm{CO}_{2}$ fluxes in Northern Great Plains grasslands is not known. The objectives of this research were to determine $\mathrm{CO}_{2}$ and water vapor fluxes over a grazed mixed-grass prairie (prairie site) and a mixed-grass prairie that has extensive invasion of shrubs (shrub prairie site). The Bowen ratio/energy balance (BREB) technique was used to determine $\mathrm{CO}_{2}$ and water vapor (ET) fluxes during a 4-year period from 1 May to 17 October in 1999, 2000, 2001, and 2002. Aboveground biomass and leaf area index (LAI) were measured about every 21 days throughout the growing season. Peak biomass occurred during July to early August and averaged $1763 \mathrm{~kg} \cdot \mathrm{ha}^{-1}$ for the prairie and $1808 \mathrm{~kg} \cdot \mathrm{ha}^{-1}$ for herbaceous locations in the shrub prairie site. LAI of the herbaceous locations averaged 0.39 for the prairie site and 0.56 for the shrub prairie site. LAI for the shrubs in the shrub prairie site averaged 4.28. Total growing season $\mathrm{CO}_{2}$ fluxes were similar in prairie and shrub prairie sites, averaging about $350 \mathrm{~g} \mathrm{CO}_{2} \cdot \mathrm{m}^{-2}$ (positive flux is $\mathrm{CO}_{2}$ uptake). However, the presence of shrubs altered the seasonal pattern of fluxes. Carbon dioxide fluxes over the shrub prairie site were higher than over the prairie site early in the growing season in May and June, and were often lower than those of the prairie site late in the growing season in August, September, and October. Evapotranspiration rates from May to mid-October were higher in the prairie $(521 \mathrm{~mm})$ than the shrub prairie site (461 mm). These results suggest that shrub invasion on Northern Great Plains grasslands does not reduce the potential of grasslands to sequester atmospheric $\mathrm{CO}_{2}$.
\end{abstract}

\section{Resumen}

Los pastizales templados son ecosistemas ricos en especies que pueden ser importantes en mitigar el incremento del $\mathrm{CO}_{2}$ atmosférico. El efecto de la invasion de arbustos en los flujos $\mathrm{CO}_{2}$ de los Pastizales de las Grandes Planicies del Norte no es conocido. Los objetivos de esta investigación fueron determinar los flujos de $\mathrm{CO}_{2}$ y vapor de agua en una pradera de zacates mixtos apacentada (sitio de pradera) y en una pradera de zacates mixtos con una fuerte invasión de arbustos (sitio de pradera con arbustos). Para determinar los flujos de $\mathrm{CO}_{2}$ y vapor de agua (ET) se uso la técnica de balance de la relación Bowen/energía y el estudio se condujo durante un periodo de 4 años del 1 de Mayo al 17 de Octubre de 1999, 2000, 2001 y 2002. La biomasa aérea y el indice de área foliar (LAI) se midieron aproximadamente cada 21 días a lo largo de la estación de crecimiento. El pico de producción de biomasa ocurrió de Julio a inicios de Agosto y promedió $1763 \mathrm{~kg} \mathrm{ha}^{-1}$ para la pradera y $1808 \mathrm{~kg}$ ha ${ }^{-1}$ para las localidades herbáceas del sitio de pradera con arbustos. El LAI de las localidades herbáceas promedio 0.39 en el sitio de pradera y 0.56 en el de pradera con arbustos. El LAI de los arbustos en el sitio de pradera con arbustos promedio 4.28. Los flujos totales de $\mathrm{CO}_{2}$ durante la estación de crecimiento fueron similares en los sitios de pradera y de pradera con arbustos, promediando aproximadamente $350 \mathrm{~g} \mathrm{CO}_{2} \mathrm{~m}^{-2}$ (el flujo positivo es la toma de $\mathrm{CO}_{2}$ ); sin embargo, la presencia de arbustos alteró el patrón estacional de los flujos. A inicios de la estación de crecimiento, en Mayo y Junio, los flujos de dióxido de carbono del sitio de pradera con arbustos fueron mayores que los del sitio de pradera, y a fines de la estación de crecimiento, en Agosto, Septiembre y Octubre, a menudo fueron mas bajos que los del sitio de pradera. Las tasas de evapotranspiración de Mayo a mediados de Octubre fueron mayores en la pradera $(521 \mathrm{~mm}$ ) que en el sitio de pradera con arbustos (461 mm). Estos resultados sugieren que la invasión de arbustos en los pastizales de las Grandes Planicies del Norte no reducen el potencial de los pastizales para secuestrar $\mathrm{CO}_{2}$ atmosférico.

Key Words: rangeland, carbon sequestration, carbon budget, Bowen ratio, natural ecosystems

\section{INTRODUCTION}

US Department of Agriculture, Agricultural Research Service, Northern Plains Area, is an equal opportunity/affirmative action employer and all agency services are available without discrimination.

The mention of commercial products in this paper is solely to provide specific information for the reader. It does not constitute endorsement by the USDA Agricultural Research Service over other products.

Correspondence: A. B. Frank, USDA-ARS, Box 459, Hwy 6 S, Mandan, ND 58554. Email: franka@mandan.ars.usda.gov

Manuscript received 5 January 04; manuscript accepted 23 March 2004
Land-use changes and increasing fossil fuel use have contributed to increased atmospheric $\mathrm{CO}_{2}$ concentrations (Watson et al. 1996). To better understand the cycling of carbon (C), researchers have identified some natural and human-influenced C sources and sinks (Rastetter et al. 1992; Schimel 1995; Fan et al. 1998). Grassland ecosystems generally have been considered an example of agricultural systems where soils are marginally productive yet contain high amounts of soil organic C, because 
the extensive fibrous root systems of grasses are effective accumulators of C. Tropical forests are the largest terrestrial biomass sinks for C, containing about $40 \%$ of the total $\mathrm{C}$ stored in terrestrial ecosystems (Dixon et al. 1994). Temperate grassland ecosystems are a vast area comprising about $32 \%$ of the earth's natural vegetation (Adams et al. 1990) and may have a significant role in the global C budget (Sundquist 1993; Batjes 1998). Temperate region ecosystems, of which grasslands are a part, also may be functioning as important $\mathrm{C}$ sinks that could contribute to reducing the rate of increase in atmospheric $\mathrm{CO}_{2}$ (Rastetter et al. 1992; Gifford 1994; Schimel 1995; Keeling et al. 1996; Fan et al. 1998). Globally, grasslands have the potential to store $54 \mathrm{MMT} \mathrm{C} \cdot \mathrm{yr}^{-1}$ (Follett 2001).

The perennial nature of most grasslands along with the usual low productivity of grassland soils raise questions about the potential of grassland ecosystems to sequester and store $\mathrm{C}$ (Cole 1996; Houghton et al. 1999). Measurements of $\mathrm{CO}_{2}$ fluxes over grasslands provide important databases to evaluate this issue. The large diversity in vegetation and variability in climate present in grassland ecosystems suggest that $\mathrm{CO}_{2}$ fluxes must be measured across a wide range of grassland to accurately estimate their role in the global $\mathrm{C}$ budget. Flux measurements for the tallgrass prairie of eastern Texas (Dugas et al. 1999) and Oklahoma (Suyker and Verma 2001), the mixed-grass prairie of Oklahoma (Sims and Bradford 2001), and the mixed-grass prairie of North Dakota (Frank and Dugas 2001) show that grasslands can be annual sinks for $\mathrm{CO}_{2}$. Generally, maximum $\mathrm{CO}_{2}$ flux coincides with periods of maximum leaf area and aboveground biomass accumulation. The size of the $\mathrm{C}$ sink in grasslands is strongly affected by the high soil organic $\mathrm{C}$ content typical of well-managed grasslands and precipitation. Soil C losses during the dormant season (nongrowing season) have been shown to be important in determining the amount of C stored on an annual basis (Frank and Dugas 2001).

The objectives of this research were to determine the magnitude of $\mathrm{CO}_{2}$ and water vapor fluxes over a grazed mixed-grass prairie site and a grazed mixed-grass prairie site that has extensive invasion of shrubs. It is hypothesized that $\mathrm{CO}_{2}$ fluxes for the 2 sites would be similar for the growing season even though vegetation differs. This research is part of the USDA-Agricultural Research Service's Rangeland $\mathrm{CO}_{2}$ Flux Project (Svejcar et al. 1997), which addresses the role of grasslands in the global $\mathrm{C}$ cycle.

\section{MATERIALS AND METHODS}

The 2 sites in this study are located at the Northern Great Plains Research Laboratory, Mandan, North Dakota (lat $46^{\circ} 46^{\prime} \mathrm{N}$, long $100^{\circ} 55^{\prime} \mathrm{W}$, elevation $518 \mathrm{~m}$ ) on slopes of 2 to $10 \%$. One site is a typical mixed-grass prairie (prairie site) that has been grazed by livestock at 2.6 ha $\cdot$ steer $^{-1}$ from mid-May to mid-October each year since 1916. The second site (shrub prairie site) is a grazed mixed-grass prairie site located approximately $1000 \mathrm{~m}$ north of the prairie site. The shrub prairie site has been grazed annually at about $2-3$ ha $\cdot$ steer $^{-1}$ from mid-May to mid-October since about 1970. Photographs of the shrub prairie site in 1923 showed the complete absence of shrubs on the landscape. Shrub invasion likely occurred mainly from lack of fire and frequent light to no grazing from 1923 until approximately 1970. The herbaceous vegetation at each site is typical of the northern mixed-grass prairie and is typical of an Agropyron-Bouteloua-Stipa grassland (Whitman and Barker 1994). The shrub prairie site differs from the prairie site in that the landscape relief is more variable and about $32 \%$ of the surface area within a 200-m radius of the flux towers consists of dense shrub patches that vary in size up to $30 \mathrm{~m}$ in diameter. Although this research was conducted on sites where management and aspect may have contributed to shrub invasion, the sites were otherwise typical of northern mixed-grass prairie. Because these factors resulted in natural shrub invasion on the shrub prairie site, and not the prairie site, suggests that only relative comparisons of these sites are acceptable. The dominant shrub present was silver buffaloberry (Sheperdia argentea Nutt) with smaller patches of western snowberry (Symphoricarpos occidentalis Hook.). Other species present, mostly as isolated individuals, were honeysuckle (Lonicera spp.), Russian olive (Elaeagnus angustifolia L.), and green ash (Fraxinus pennsylvanica Sarg.). The average height of the herbaceous canopy was 0.3 to $0.5 \mathrm{~m}$, and height of shrub patches ranged from 1 to $2.5 \mathrm{~m}$. The soil at the sites is a Werner-Sen-Chama complex (loamy, mixed, superactive, frigid shallow Entic Haplustoll; fine-silty, mixed, superactive, frigid Typic Haplustoll; fine-silty, mixed, superactive, frigid Typic Calciustoll). Soil organic carbon to 1.1-m depth for the prairie site in 1993 was $11.7 \mathrm{~kg} \cdot \mathrm{C} \cdot \mathrm{m}^{-2}$ (Frank et al. 1995). These sites had not been fertilized, treated with herbicides, or burned for at least 30 years prior to the initiation of flux measurements.

Plant biomass and green leaf area of the herbaceous component within the prairie and shrub prairie sites were measured by surface clipping 4 representative $0.25-\mathrm{m}^{2}$ quadrats located about 20-60 $\mathrm{m}$ in each direction from the flux towers about every 21 days beginning in mid-April through midOctober each year in 1999, 2000, 2001, and 2002. Leaves were manually separated from stems, and leaf area was measured using a belt-driven photoelectric area meter. Green leaves, green stems, and dead material were oven dried at $70^{\circ} \mathrm{C}$ for 72 hours and weighed to obtain total aboveground live and dead biomass. Leaf area of the shrub component within the shrub prairie site was measured each year in mid-July by clipping 4 representative $1-\mathrm{m}^{2}$ quadrats in shrub patches near the herbaceous vegetation sample locations. The shrub biomass samples were processed the same as the herbaceous samples.

Soil water content (SWC) was monitored to 1.2-m depth by neutron attenuation on 8 dates in 1999 and 10 dates in 2000, 2001, and 2002. Two access tubes were located within $5 \mathrm{~m}$ of the instrument towers to measure SWC of representative herbaceous locations in the prairie and shrub prairie sites. Two access tubes were also located in shrub patches in the shrub prairie site.

Twenty-minute averages of $\mathrm{CO}_{2}$ and water vapor fluxes were measured from 1 May through 17 October in 1999, 2000, 2001, and 2002 using Bowen ratio/energy balance (BREB) instrumentation (Model $023 / \mathrm{CO}_{2}$ Bowen ratio system, Campbell Scientific, Inc., Logan, Utah) mounted on a flux tower at each site to provide at least $200 \mathrm{~m}$ of fetch in all directions from the towers. The flux tower in the shrub prairie site was located in an exposed, slightly elevated area to reduce the effects of the canopy roughness created by the shrub patches. Fluxes were calculated using methods described by Dugas (1993) and Dugas 
Table 1. Precipitation during the flux measurement period of 1 May to 17 October during 1999, 2000, 2001, and 2002. Numbers in parentheses are annual precipitation for each year.

\begin{tabular}{|c|c|c|}
\hline Year & Prairie & Shrub Prairie \\
\hline & \multicolumn{2}{|c|}{$(\mathrm{mm})$} \\
\hline 1999 & $493(511)$ & 475 (493) \\
\hline 2000 & 305 (492) & 310 (497) \\
\hline 2001 & $375(534)$ & $382(541)$ \\
\hline 2002 & 166 (288) & $150(212)$ \\
\hline Means & $335(456)$ & 347 (436) \\
\hline
\end{tabular}

et al. (1999). Bowen ratios were calculated from temperature and humidity gradients measured every 2 seconds from arms at 1 and $2 \mathrm{~m}$ above the canopy. Sensible heat flux was calculated from the Bowen ratio, average net radiation (Model $\mathrm{Q} * 7$ net radiometer, REBS, Seattle, Washington), and average soil heat flux calculated from 2 soil heat flux plates (Model HFT, REBS) and soil temperatures measured above the plates. The net radiometer was calibrated against a laboratory standard over grass vegetation each year before use. Calibrations showed that sensor sensitivities were constant over years. The turbulent diffusivity, assumed equal for heat, water vapor, and $\mathrm{CO}_{2}$, was calculated using the 20-minute sensible heat flux and temperature gradient measurements. Twenty-minute averages of $\mathrm{CO}_{2}$ flux, corrected for vapor density differences at the 2 heights (Webb et al. 1980), were calculated as a product of turbulent diffusivity and the 20-minute average $\mathrm{CO}_{2}$ gradient that was measured along with the humidity. When the BREB method for calculating turbulent diffusivity was not valid because of differences in the sign of the sensible/latent heat flux and the temperature/humidity gradient, turbulent diffusivity was calculated using wind speed, atmospheric stability, and canopy height (Dugas et al. 1999). Canopy height of the herbaceous component of the vegetation was measured at least 3 times each growing season. The alternative method was used approximately $10 \%$ of the time and those instances occurred almost exclusively at night, when $\mathrm{CO}_{2}$ and water vapor gradients were small (Dugas et al. 1999). Carbon dioxide and water vapor concentration gradients between the 2 heights were measured with an infrared gas analyzer (Model 6262, Li-Cor, Inc., Lincoln, Nebraska). The airstream from each arm was switched between the 2 analyzer cells every 2 minutes. Analyzers were calibrated weekly using a gas mixture of near-ambient $\mathrm{CO}_{2}$ concentration. Fluxes were not corrected for temperature differences in the 2 airstreams, because in tests described by Angell et al. (2001), fine wire thermocouple measurements indicated air temperatures from the 2 arms were not different when entering the sample and reference chambers of the analyzer. Measurements from the BREB system were averaged every 20 minutes and stored with a data logger (Model 21X, Campbell Scientific, Inc.).

Over the course of the study, equipment malfunction caused the loss of some 20-minute flux averages. The longest period of data loss occurred during a 5 -day period from 24 June to 29 June 2000 due to instrument malfunction. Average daily $\mathrm{CO}_{2}$ and water vapor fluxes over 10-day periods were calculated and reported here. Standard errors of the mean were calculated for

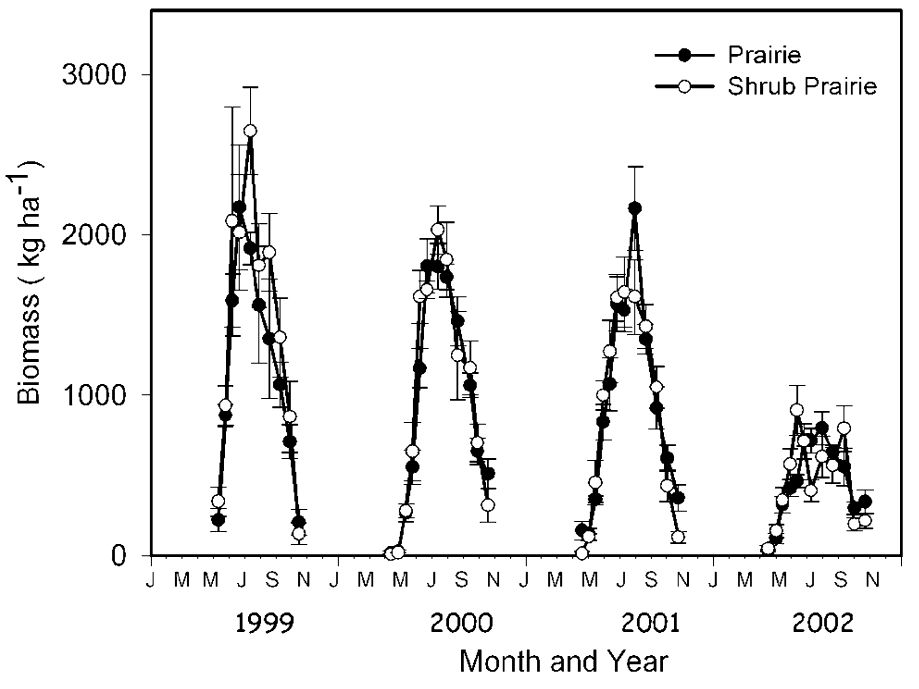

Figure 1. Seasonal measurements of aboveground green biomass for prairie and shrub prairie sites. The clippings were made about every 21 days beginning in mid-April to mid-October in 1999, 2000, 2001, and 2002. Vertical bars on the symbols are standard errors of the mean.

the 10-day means and for the seasonal fluxes. Missing days were not included in daily flux averages. Positive $\mathrm{CO}_{2}$ fluxes represent uptake by the vegetation.

\section{RESULTS AND DISCUSSION}

The long-term (85 years) annual precipitation at a weather station located about $4 \mathrm{~km}$ north from the field sites is $404 \mathrm{~mm}$. Annual precipitation totals during this study were greatest in 2001 when the prairie site received $534 \mathrm{~mm}$ and the shrub prairie site received $541 \mathrm{~mm}$, and lowest in 2002 when precipitation totals at both sites were about half of the 2001 totals (Table 1). Precipitation during the flux measurement periods each year from 1 May to 17 October was similar for

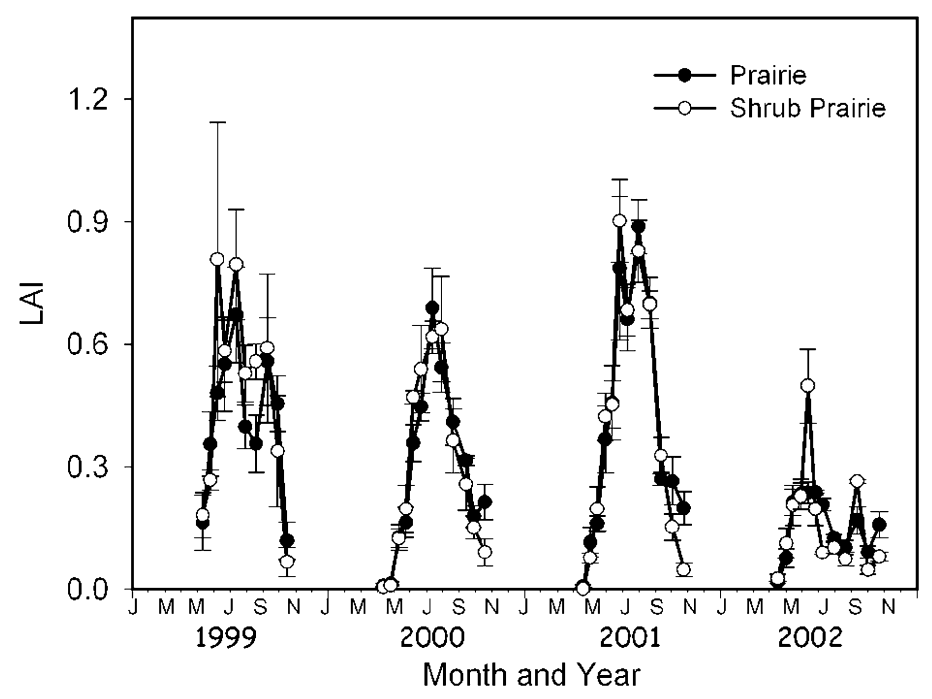

Figure 2. Seasonal measurements of leaf area index (LAl) for a prairie and shrub prairie site. The clippings were made about every 21 days beginning in mid-April to mid-October in 1999, 2000, 2001, and 2002. Vertical bars on the symbols are standard errors of the mean. 
Table 2. Leaf area index ( $\mathrm{LAI}$ ) and standard errors of the mean (SE) for herbaceous and shrub locations within the prairie and shrub prairie sites averaged for mid-June dates in 1999, 2000, 2001, and 2002.

\begin{tabular}{lcccccccc}
\hline & \multicolumn{2}{c}{$\begin{array}{c}\text { Prairie-Herbaceous } \\
\text { Locations }\end{array}$} & & \multicolumn{2}{c}{$\begin{array}{c}\text { Shrub Prairie-Herbaceous } \\
\text { Locations }\end{array}$} & & \multicolumn{2}{c}{$\begin{array}{c}\text { Shrub Prairie-Shrub } \\
\text { Patches }\end{array}$} \\
\cline { 2 - 3 } Year & LAI & SE & & LAI & SE & & LAI & SE \\
\hline 1999 & 0.48 & $(0.07)$ & & 0.81 & $(0.34)$ & & 4.17 & $(0.73)$ \\
2000 & 0.36 & $(0.05)$ & & 0.47 & $(0.02)$ & & 5.62 & $(0.68)$ \\
2001 & 0.46 & $(0.09)$ & & 0.45 & $(0.05)$ & & 3.86 & $(0.74)$ \\
2002 & 0.24 & $(0.03)$ & & 0.50 & $(0.09)$ & & 3.46 & $(0.45)$ \\
Means & 0.39 & & & 0.56 & & & 4.28 & \\
\hline
\end{tabular}

both sites and ranged from $150 \mathrm{~mm}$ for the shrub prairie site in 2002 to a high of $493 \mathrm{~mm}$ for the prairie site in 1999. The longterm average precipitation for 1 May to 17 October is $321 \mathrm{~mm}$. An unusually high amount of precipitation received in a singleday, high-intensity event in August 1999 was not effective precipitation for biomass accumulation. Historically, the greatest mean monthly precipitation occurs in June when $21 \%$ of the annual precipitation is received.

Peak photosynthesizing green biomass typically occurred during July to early August for both sites (Fig. 1). Within years biomass was similar for both sites, whereas among sites and years peak biomass was greatest in the shrub prairie site in $1999\left(2649 \mathrm{~kg} \cdot \mathrm{ha}^{-1}\right)$ and least in the prairie site during the drought year of $2002\left(796 \mathrm{~kg} \cdot \mathrm{ha}^{-1}\right)$. Peak aboveground biomass across the 4 years averaged $1763 \mathrm{~kg} \cdot \mathrm{ha}^{-1}$ for the prairie site and $1808 \mathrm{~kg} \cdot \mathrm{ha}^{-1}$ for the shrub prairie site. The variation in biomass across the 4-year period is supported by the results of Rogler and Haas (1947) who reported that aboveground biomass production from mixed-grass prairie grasslands is primarily a function of timing and quantity of precipitation.

Maximum leaf area index (LAI) was similar for both sites in 1999, 2000, and 2001, but much lower during the drought year of 2002 (Fig. 2). Maximum LAI occurred at similar times as peak biomass. Average LAI across sites and years ranged from 0.24 for the prairie site in 2002 to 0.81 for the herbaceous component within the shrub prairie site in 1999 (Table 2). The average LAI across all sample dates and years was 0.39 for the prairie site and 0.56 for the shrub prairie site. The greater LAI for the herbaceous component in the shrub prairie site was mainly due to the presence of a greater proportion of broadleaf forbs being present in the shrub prairie site herbaceous component samples than in the prairie site samples. The shrub patches in the shrub prairie site had an LAI that ranged from 3.46 in 2002 to 5.62 in 2000 (Table 2) or about 6 times greater than the maximum LAI for the herbaceous component from the shrub prairie and prairie sites. The greater LAI for the shrub prairie site on the fifth sampling date compared to the other sampling dates in 2002 was due to a greater proportion of broadleaf forbs than on the other sampling dates (Fig. 2). Both biomass and LAI were influenced by precipitation with 2002 having the lowest precipitation and correspondingly the lowest biomass and LAI of all years in the study.

Average 10-day $\mathrm{CO}_{2}$ fluxes were greater on the shrub prairie site than the prairie site early in the growing season during May
Table 3. Carbon dioxide flux and evapotranspiration (ET) for prairie and shrub prairie sites from 1 May to 17 October for 1999, 2000, 2001, and 2002. Positive flux is $\mathrm{CO}_{2}$ uptake. Data are the cumulative sum of daily $\mathrm{CO}_{2}$ flux and ET. Standard errors of the mean are in parentheses.

\begin{tabular}{|c|c|c|c|c|}
\hline \multirow[b]{2}{*}{ Year } & \multicolumn{2}{|c|}{$\mathrm{CO}_{2}$ Flux } & \multicolumn{2}{|c|}{ ET } \\
\hline & Prairie & Shrub Prairie & Prairie & Shrub Prairie \\
\hline & \multicolumn{2}{|c|}{$\left(\mathrm{g} \mathrm{CO}_{2} \cdot \mathrm{m}^{-2}\right)$} & \multicolumn{2}{|c|}{$\left(\mathrm{mm} \mathrm{H}_{2} \mathrm{O}\right)$} \\
\hline 1999 & $251(2)$ & $796(5)$ & $554(3)$ & $518(5)$ \\
\hline 2000 & $438(3)$ & $257(2)$ & $551(3)$ & $450(3)$ \\
\hline 2001 & $619(4)$ & $446(3)$ & $583(4)$ & $495(3)$ \\
\hline 2002 & $89(1)$ & $-101(1)$ & $394(3)$ & $380(3)$ \\
\hline Means & 349 & 350 & 521 & 461 \\
\hline
\end{tabular}

and June. Fluxes were similar on the 2 sites during peak biomass accumulation during July. Later in the growing season, from late-July to mid-October, $\mathrm{CO}_{2}$ fluxes were greatest on the prairie site (Fig. 3). During the May and June period, fluxes for the shrub prairie site averaged $5.3 \mathrm{~g} \mathrm{CO}_{2} \cdot \mathrm{m}^{-2} \cdot \mathrm{d}^{-1}$ compared to $2.2 \mathrm{~g} \mathrm{CO}_{2} \cdot \mathrm{m}^{-2} \cdot \mathrm{d}^{-1}$ for the prairie site. Flux rates for both sites were influenced by precipitation after the initial increase in biomass and LAI during May and June. Limited precipitation received during mid-June to mid-July caused a rapid decline in $\mathrm{CO}_{2}$ flux to near zero for both sites. Precipitation that occurred from mid-July to mid-August increased $\mathrm{CO}_{2}$ fluxes rapidly for the prairie site, but fluxes for the shrub prairie site did not recover. Limited precipitation from mid-August to mid-October caused negative or near-negative fluxes for both sites. During mid-July to mid-October fluxes averaged $1.77 \mathrm{~g} \mathrm{CO}_{2} \cdot \mathrm{m}^{-2}$. $\mathrm{d}^{-1}$ for the prairie site, but only $-0.1 \mathrm{~g} \mathrm{CO}_{2} \cdot \mathrm{m}^{-2} \cdot \mathrm{d}^{-1}$ for the shrub prairie site. Polley et al. (1997) concluded that, since shrubs can use soil water from deeper depths than grasses, an increase in soil water favors shrubs in a water-limited grassland-shrub ecosystem. However, on a seasonal basis, our data show that $\mathrm{CO}_{2}$ fluxes over the herbaceous-dominated prairie site showed a greater response to precipitation events during mid- to late-season than did the shrub prairie site.

The $\mathrm{CO}_{2}$ fluxes during the growing season were positive for 7 of the 8 site-seasons of flux measurements indicating $\mathrm{CO}_{2}$ uptake, but fluxes varied widely within sites and were greater for the prairie site 3 of the 4 seasons (Table 3). Fluxes for the growing season at the prairie site ranged from $89 \mathrm{~g} \mathrm{CO} 2 \cdot \mathrm{m}^{-2}$ in 2002 to $619 \mathrm{~g} \mathrm{CO}_{2} \cdot \mathrm{m}^{-2}$ in 2001, whereas the range in fluxes for the shrub prairie site was greater, ranging from $-101 \mathrm{~g} \mathrm{CO}_{2} \cdot \mathrm{m}^{-2}$ in 2002 to $796 \mathrm{~g} \mathrm{CO}_{2} \cdot \mathrm{m}^{-2}$ in 1999 or nearly an 8 -fold difference. The lowest $\mathrm{CO}_{2}$ fluxes for both sites occurred during the drought year of 2002. Carbon dioxide fluxes were similar across the growing season years averaging $349 \mathrm{~g} \mathrm{CO}_{2} \cdot \mathrm{m}^{-2}$ for the prairie site and $350 \mathrm{~g} \mathrm{CO}_{2} \cdot \mathrm{m}^{-2}$ for the shrub prairie site.

Water vapor fluxes or evapotranspiration (ET) increased rapidly during the period of rapid biomass accumulation (May and June), reached maximum rates during July to early-August, and then decreased rapidly to mid-October (Fig. 4). Although differences among both sites and years were small, ET at the prairie site was consistently greater than that at the shrub prairie site. Differences in growing season ET between the 2 


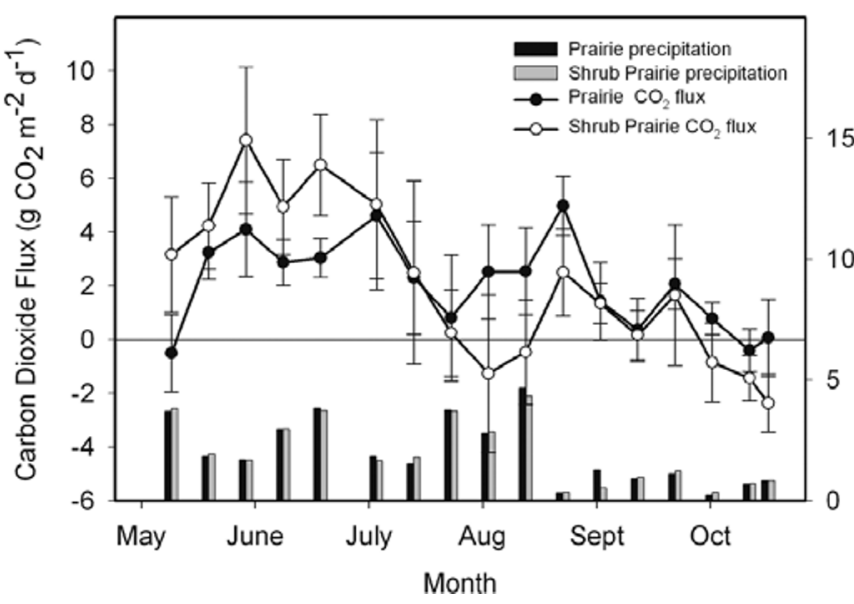

Figure 3. Ten-day daily average $\mathrm{CO}_{2}$ fluxes for prairie and shrub prairie sites across years from 1 May to 17 October in 1999, 2000, 2001, and 2002. Vertical bars on the symbols are standard errors of the mean. The horizontal bars on the $x$-axis are daily average precipitation for 10-day periods. Positive flux indicates $\mathrm{CO}_{2}$ uptake.

sites ranged from only $14 \mathrm{~mm}$ in 2002 to $101 \mathrm{~mm}$ in 2000 (Table 3). Four-year average ET was $521 \mathrm{~mm}$ for the prairie site and $461 \mathrm{~mm}$ for the shrub prairie site. The trend for lower ET for the shrub prairie site can be attributed to shrubs generally having lower transpiration rates than grass species. The shrub patches have a much denser canopy structure, LAI (Table 2), compared to the herbaceous component at both sites, which often results in energy relationships that reduces ET. Also, the leaves of silver buffaloberry are small and silvery, traits which contribute to drought hardiness and reduced water use. Mesquite (Prosopis glandulosa Torr.), an invasive tree in the Southern Great Plains grasslands of Texas, possesses water conservation mechanisms that close stomata during the high air temperature periods of the year which reduces ET, even if soil water is available (Wan and Sosebee 1991). Similar mechanisms may be operating in silver buffaloberry in this study as the period of greatest difference in ET between the prairie and shrub prairie sites occurred during June, July, and August when daily maximum air temperatures were highest averaging 21.4, 26.3 , and $25.7^{\circ} \mathrm{C}$, respectively. Daily maximum air temperatures were much higher across June, July, and August ranging from $37.7^{\circ} \mathrm{C}$ in 2001 to $43.4^{\circ} \mathrm{C}$ in 2002 .

The average SWC on sample dates across the 4 growing seasons trended higher for the shrub patches within the shrub prairie site than the herbaceous component locations within the prairie and prairie shrub sites (Fig. 5). The SWC for the herbaceous component locations within the prairie and shrub prairie sites were similar during the season. The SWC for the prairie site, shrub prairie site, and shrub location within the shrub prairie site decreased similarly throughout the growing season. During the drought year of 2002, the minimum SWC at any time during the study was measured on 3 October and averaged $173 \mathrm{~mm}$ for the prairie site, $209 \mathrm{~mm}$ for the shrub prairie site, and $234 \mathrm{~mm}$ for the shrub patches in the shrub prairie site. If we consider the minimum SWC for the prairie site as the minimum point of soil water extraction (Haise et al. 1955), then total water extracted by the shrub patches is less

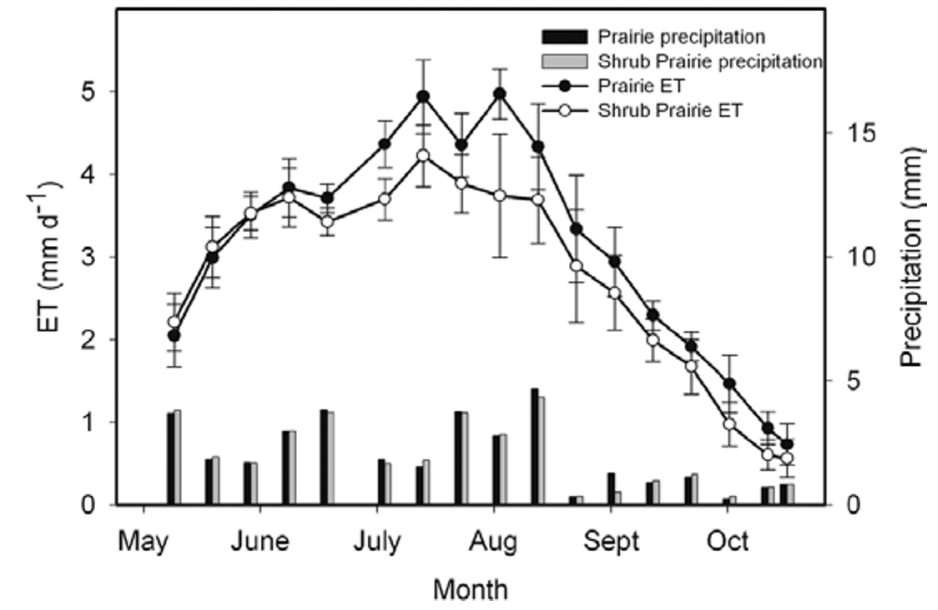

Figure 4. Ten-day average evapotranspiration (ET) rates for prairie and shrub prairie sites across years from 1 May to 17 October in 1999, 2000, 2001, and 2002. Vertical bars on the symbols are standard errors of the mean. The horizontal bars on the $x$-axis are daily average precipitation for 10-day periods.

than for the herbaceous component locations within the prairie and shrub prairie sites. Thus, the lower ET for the shrub prairie site compared to the prairie site can be partially explained by less soil water being extracted by the shrub patches than by the herbaceous component locations within the prairie and shrub prairie sites. Alternatively, the greater SWC of the shrub patches may be partly due to the hydraulic lift phenomena characteristic of Artemisia tridentata whereby plant roots move water from deeper to shallower depths of the soil profile (Richards and Caldwell 1987). Although the shrub patches in the shrub prairie site had a greater LAI and exhibited little visual evidence of leaf senescence or environmental stresses, the shrubs apparently could not utilize the available soil water to enhance $\mathrm{CO}_{2}$ uptake from August to mid-October, a period when fluxes were generally less for the prairie shrub site (Fig. 3).

Although native grassland ecosystems in semiarid environments are perceived to be at equilibrium or a small sink for C (Sims and Singh 1978, Bruce et al. 1999, Dugas et al. 1999, Frank and Dugas 2001, Pacala et al. 2001, Jackson et al. 2002), increased atmospheric $\mathrm{CO}_{2}$ concentrations have been suggested by some to favor increased carbon storage through woody plant encroachment into grasslands (Mayeux et al. 1992). Invasion of shrubs on grassland sites in Colorado, New Mexico, and Texas has been shown to increase $\mathrm{C}$ stock of arid sites, but decrease $\mathrm{C}$ stocks in the wetter sites (Jackson et al. 2002). From their study, Jackson et al. (2002) concluded that $C$ was lost from soils when woody plant invasion occurred on wetter sites ( 600-1000-mm precipitation), but soil C levels on drier sites ( $200-400-\mathrm{mm}$ precipitation) were maintained. Our results suggest that there were no differences in the amount of $\mathrm{C}$ uptake between the prairie sites with or without shrubs. Although wide differences were present in short-term seasonal $\mathrm{CO}_{2}$ fluxes between the prairie and shrub prairie sites, seasonlong $\mathrm{CO}_{2}$ fluxes were similar when averaged over 4 years. Although the data suggest that shrub invasion into Northern Great Plains grasslands does not reduce $\mathrm{CO}_{2}$ uptake there may be an impact on forage production for grazing livestock. Also, 


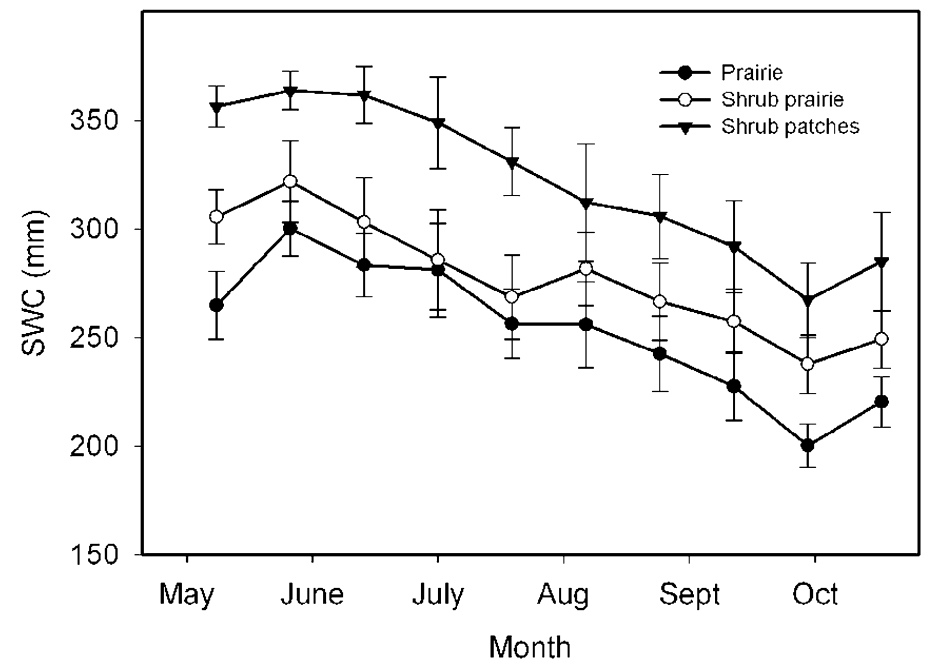

Figure 5. Seasonal pattern in soil water content (SWC) to 1.2-m depth for the prairie site, shrub prairie site, and shrub patches within the shrub prairie site averaged across 1999, 2000, 2001, and 2002. Vertical bars on the symbols are standard errors of the mean.

some level of shrub invasion into grasslands may have advantages for wildlife habitat and enhancing species diversity.

In this study we did not measure $\mathrm{CO}_{2}$ fluxes during the grasslands dormant season. However, in a similar study on Northern Great Plains mixed-grass prairie dormant season fluxes of $1.4 \mathrm{~g} \mathrm{CO}_{2} \cdot \mathrm{m}^{-2} \cdot \mathrm{d}^{-1}$ were reported (Frank and Dugas 2001). Based on these dormant season $\mathrm{CO}_{2}$ flux rates, $-263 \mathrm{~g} \mathrm{CO}_{2}$. $\mathrm{m}^{-2}$ would be lost to the atmosphere during the 188-day dormant season during this study. Combining these dormantseason flux rates with the average growing season $\mathrm{CO}_{2}$ fluxes for this study of $350 \mathrm{~g} \mathrm{CO}_{2} \cdot \mathrm{m}^{-2}$ would give annual fluxes of $87 \mathrm{~g} \mathrm{CO}_{2} \cdot \mathrm{m}^{-2}$, which suggests that these ecosystems remain a small sink for atmospheric $\mathrm{CO}_{2}$.

\section{LITERATURE CITED}

Adams, J. M., H. Falre, L. Falre-Richard, J. M. McGlade, and F. I. Woodward. 1990. Increases in terrestrial carbon storage from the last glacial maximum to the present. Nature 348:711-714.

Angell, R., T. Svejcar, J. Bates, N. Z. Saliendra, and D. A. Johnson. 2001. Carbon dioxide flux measurements on 2 sagebrush steppe sites: Bowen ratio and closed chamber comparisons. Agricultural and Forest Meteorology 108:153161.

BATJES, N. H. 1998. Mitigation of atmospheric $\mathrm{CO}_{2}$ concentrations by increased carbon sequestration in the soil. Biology and Fertility of Soils 27:230-235.

Bruce, J. P., M. Frome, E. Haites, H. Janzen, R. Lal, and K. Paustian. 1999. Carbon sequestration in soils. Journal of Soil and Water Conservation 54:382-389.

Cole, V. 1996. Agricultural options for mitigation of greenhouse gas emissions. In: R. T. Watson, M. C. Zinyowerea, and R. H. Moss (eds.). Climate change 1995. Impacts, adaptations and mitigation of climate change: Scientifictechnical analyses. Cambridge: Cambridge University Press. p 747-771.

Dixon, R. K., S. Brown, R. A. Houghton, A. M. Solomon, M. C. Trexler, and J. WISNIEWSKI. 1994. Carbon pools and flux of global forest ecosystems. Science 263:185-190.

Dugas, W. A. 1993. Micrometeorological and chamber measurements of $\mathrm{CO}_{2}$ flux from bare soil. Agricultural and Forest Meteorology 67:115-128.

Dugas, W. A., M. L. Heuer, and H. S. Mayeux. 1999. Carbon dioxide fluxes over bermudagrass, native prairie, and sorghum. Agricultural and Forest Meteorology 93:121-139.
Fan, S., M. Gloor, J. Mahlman, S. Pacala, J. Sarmiento, T. Takahashi, and P. Tans. 1998. A large terrestrial carbon sink in North America implied by atmospheric and oceanic carbon dioxide data and models. Science 282:442-446.

Follett, R. F. 2001. Organic carbon pools in grazing land soils. In: R. F. Follett, J. M. Kimble and R. Lal (eds.). The potential of U.S. grazing lands to sequester carbon and mitigate the greenhouse effect. Boca Raton, FL: Lewis Publishers. p 65-86.

Frank, A. B. and W. A. Dugas. 2001. Carbon dioxide fluxes over a northern semiarid, mixed-grass prairie. Agricultural and Forest Meteorology 108:317326.

Frank, A. B., D. L. Tanaka, L. Hofmann, and R. F. Follett. 1995. Soil carbon and nitrogen of Northern Great Plains grasslands as influenced by long-term grazing. Journal of Range Management 48:470-474.

GifFORD, R. M. 1994. The global carbon cycle: a viewpoint on the missing sink. Australian Journal of Plant Physiology 21:1-15.

HaIse, H. R., H. J. HAAS, AND L. R. JenSEN. 1955. Soil moisture studies of some great plains soils: II. Field capacity as related to $1 / 3$-atmosphere percentage, and "minimum point" as related to 15- and 26-atmosphere percentages. Soil Science Society of America Proceedings 19:20-25.

Houghton, R. A., J. L. Hacker, and K. T. LAWRence. 1999. The U. S. carbon budget: contributions from land-use change. Science 285:574-578.

Jackson, R. B., J. L. Banner, E. G. Jobbágy, W. T. Pockman, and D. H. Wall. 2002. Ecosystem carbon loss with woody plant invasion of grasslands. Nature 418:623-626.

Keeling, C. D., J. F. S. Chin, And T. P. WhoRf. 1996. Increased activity of northern vegetation inferred from atmospheric $\mathrm{CO}_{2}$ measurements. Nature 382: 146-149.

Mayeux, H. S., H. B. Johnson, and H. W. Polley. 1992. Global change and vegetation dynamics. In: Lynn James, John 0. Evans, Michael H. Ralphs, and R. Dennis Child (eds.). Noxious range plants. Boulder, CO: Westview Press. p 62-73.

Pacala, S. W., G. C. Hunt, D. Baker, P. Peylin, R. A. Houghton, R. A. Birdsey, L. Heath, E. T. Sunquist, R. F. Stallard, P. Cials, P. Moorcroft, J. P. Caspersen, E. Shevliakova, B. Moore, G. Kohlmaier, E. Holland, M. Gloor, M. E. Harmon, S. M. Fan, J. L. Sarmiento, C. L. Goodale, D. Schimel, and C. B. Field. 2001. Consistent land- and atmosphere-based U.S. carbon sink estimates. Science 292:2316-2320

Polley, H. W., H. S. Mayeux, H. B. Johnson, and C. R. Tischler. 1997. Viewpoint: atmospheric $\mathrm{CO}_{2}$, soil water, and shrub/grass ratios on rangelands. Journal of Range Management 50:278-284.

Richards, J. H. AND M. M. Caldwell. 1987. Hydraulic lift: substantial nocturnal water transport between soil layers by Artemisia tridentata roots. Oceologia 73:486-489.

Rastetter, E. B., R. B. McKane, G. R. Shaver, and J. M. Melillo. 1992. Changes in $\mathrm{C}$ storage by terrestrial ecosystems: how $\mathrm{C}-\mathrm{N}$ interactions restrict responses to $\mathrm{CO}_{2}$ and temperature. Water, Air, and Soil Pollution 64:327-344.

RogleR, G. A. AND H. J. HAAs. 1947. Range production as related to soil moisture and precipitation on the Northern Great Plains. Agron. J. 39:378-389.

ScHImeL, D. S. 1995. Terrestrial ecosystems and the carbon cycle. Global Change Biology 1:77-91.

Sims, P. L. AND J. A. Bradford. 200l. Carbon dioxide fluxes in a southern plains prairie. Agricultural and Forest Meteorology 109:117-134.

Sims, P. L. AND J. S. Singh. 1978. The structure and function of ten western North American Grasslands. IV. Compartmental transfers and energy flow within the ecosystem. Journal of Ecology 66:983-1009.

Sundquist, E. T. 1993. The global carbon dioxide budget. Science 259:934-941.

SuYKeR, A. E. AND S. B. Verma. 2001. Year-round observations of the net ecosystem exchange of carbon dioxide in a native tallgrass prairie. Global Change Biology 7:279-289

Svejcar, T., H. Mayeux, and R. Angell. 1997. The rangeland carbon dioxide flux project. Rangelands 19:16-18.

Wan, C. AND R. E. SosebeE. 1991. Water relations and transpiration of honey mesquite on 2 sites in west Texas. Journal of Range Management 44:156160.

Watson, R. T., M. C. Zinyowerea, And R. H. Moss. (eds.) 1996. Climate change 1995. 
Impacts, adaptations, and mitigation of climate change: scientific-technical analyses. Contribution of working group II to the second assessment report of the Intergovernmental-Panel on Climate Change. Cambridge: Cambridge University Press.

WebB, E. K., G. I. Pearman, and R. Leuning. 1980. Correction of flux measurements for density effects due to heat and water vapor transfer. Quarterly Journal of the Royal Meteorological Society 106:85-100.

WhitMAn, W. C. AND W. T. BARKER. 1994. Wheatgrass-grama-needlegrass SRM 608. In: Thomas N. Schiflet [ed.]. Rangeland cover types of the United States. Denver, C0: Society for Range Management. p 77-78.

\section{ATTENTION READERS IMPORTANT INFORMATION REGARDING ONLINE ACCESS}

\section{You can now read the latest issue of Rangeland Ecology \& Management online at www.srmjournals.org!}

SRM Member Subscribers: SRM members who subscribe to REM will require a User ID Number and Password to gain full access to the online REM. Everyone has a unique number. Your User ID Number is your SRM member ID number and your password is your last name.

Individual Subscribers: You will require a User ID Number and Password to gain full access to the online REM. Your User ID Number is located on the address label of your journal. It is the six digits located within the parentheses above your name. Your password is your last name.

Institutional Subscribers: You will gain full access to the online REM through IP addresses. If you have not already submitted your range of IP addresses for your institution, please send them to srma@allenpress.com.

\section{Questions?}

SRM Members: contact lradtke@ rangelands.org

Subscribers: contact srma@allenpress.com 